\title{
Induction of Micronuclei, Base-pair Substitution Mutation and Excision-repair Deficient by Polluted Water from Asa River in Nigeria
}

\author{
1,2Anifowoshe T Abass*, 3Oladipo S Olayinka, ${ }^{1}$ Adebayo $O$ Mutolib, ${ }^{1}$ Eboh O Solomon, ${ }^{1}$ Abdus- \\ salam, A Rasheedat, ${ }^{1}$ Adegbenro A Monsuru, ${ }^{1}$ Ojo T Ifeoluwa, ${ }^{1}$ Adetunji A Kehinde, ${ }^{1}$ Yekeen $O$ \\ Habeeb, ${ }^{1}$ Adebiyi A Koyumat; ${ }^{1}$ Tijani $O$ Sherifat, ${ }^{1}$ Oladipupo $O$ Rasheedat, ${ }^{4}$ Abdulkareem I \\ Saratu
}

${ }^{1}$ Cell Biology and Genetics Unit, Department of Zoology, Faculty of Life Sciences, University of Ilorin, Ilorin, Nigeria. ${ }^{2}$ Department of Molecular Reproduction, Development and Genetics, Indian Institute of Science, Bangalore, India

${ }^{3}$ Zoology Unit, Department of Biosciences and Biotechnology, Kwara State University, Malete, Nigeria.

${ }^{4}$ Fisheries and Hydrobiology Unit, Department of Zoology, Faculty of Life Sciences, University of Ilorin, Ilorin, Nigeria

Received 23 ${ }^{\text {rd }}$ May, 2019, Accepted 30 th $^{\text {October, }} 2019$

DOI: 10.2478/ast-2019-0012

*Corresponding author

Anifowoshe T.Abass E-mail: anifowoshe.at@unilorin.edu.ng anifowoshea@iisc.ac.in

Tel: $+91-9148044991$

\begin{abstract}
Asa river is a major river designated to supply millions of people of Ilorin, Kwara State, Nigeria potable water for drinking but its managements is of grave concern due to anthropogenic activities. Thus, evaluation of genotoxicity of this river was carried out by subjecting the water samples and fish therein to three bioassays (Micronucleus (MN) assay, Ames test and SOS-chromo test). Physicochemical parameters and heavy metals were analysed at three different stations (Aliara (SI), Unity (SII) and Tuyil (SIII)) of the river. In SII, most of the heavy metals analysed were above the acceptable limits compare to SI and SIII. The peripheral erythrocyte of the fishes (Oreochromis niloticus, Synodontis batensoda, Synodontis eupterus, Clarias gariepinus and Clarias angullaris) at SI and SII stations showed a significant $(\mathrm{p}<0.05)$ induction of MN and different nuclear abnormalities (NA). Water samples from the three stations subjected to Ames test (Salmonella typhimurium TA100) and SOS chromotests (Escherichia coli PQ37) at $25 \%, 50 \%$ and $100 \%$ concentrations showed statistically significant $(\mathrm{p}<0.05)$ induction of DNA damage at all concentrations in the two tester strains, thus indicating base-pair substitution mutation and excision-repairdeficient, respectively, by the water samples. Therefore, drinking of this water and/or consumption of fish from this river should be taken with caution to avoid a carcinogenic risk.
\end{abstract}

Keywords: Asa river, Base-pair substitution mutation; excision-repair deficient; micronucleus; genotoxicity 


\subsection{Introduction}

One of the major resources for life is water. Globally, human activities in agriculture, industry, power generation, urbanization and transportation are of great concern as it results in the emission of several wastes products in solid, liquid or gaseous forms into the waterbodies (Ayoola, 2008). The most important freshwater resource for human is river. In spite of this, rivers are being polluted indiscriminately by anthropogenic activities, thus leading to the imbalance or fluctuation in the physico-chemical characteristics of the waterbodies (Koshy and Nayar, 1999). This imbalance could potentially pose a change to the genetic material of an animal and consequently promote a series of biological alterations (Lee and Steinert, 2003). For instance, high levels of exogenous substance such as chemicals in the rivers could generate intracellular reactive oxygen species (ROS), thus disrupting the nervous, circulatory and respiratory systems and at molecular level, it could affect the expression of genes. Persistence of this intracellular ROS could result in death of the aquatic organisms (Llobet et al., 2003). In addition, these external substances have also been reported to be genotoxic and mutagenic in plants and animals as well as human lymphocyte (Alabi and Bakare, 2011; Alabi et al., 2016). Many freshwater contaminants are toxic to the cell of the organisms as well as mutagenic, carcinogenic and/or clastogenic effects (Kligerman, 1982; Nwani et al., 2011; Kushwaha et al., 2012 and Anifowoshe et al., 2018).

Asa river is a major river designed to supply millions of people of Ilorin, Kwara State, Nigeria potable water for drinking and domestic activities. According to Kolawole et al., (2011), it is one of the major rivers in Ilorin - the capital city of Kwara State, Nigeria use for drinking and agriculture. However, domestic wastes, agricultural wastes and chemicals from many industries located along its course are discharge into the river, thus contributing to its pollution (Adekunle and Eniola, 2008). Two decades ago, Omotosho, (1998) reported that there were 21 species of fish from 10 families in this river due to low level of pollutants, however, in 2005, high level of eutrophication as a result of effluents and organic matter discharged into the river was reported (Eletta et al. 2005). This high level of eutrophication is capable of affecting the abundance of fish in this river and/or causing a deleterious effect in fish.

Genotoxic effects of an agent capable of causing DNA damage in aquatic organisms such as fish can be detected using different assays. Although different species of fish respond in different way to genotoxic agents, however, micronucleus (MN) assay is one of the most sensitive and reliable assays to uncover DNA damage in fish. It is a test used for detecting MN resulting from either chromosome loss events in anaphase damage or chromosomal breakage during cell division (Kim and Hyun, 2006; Bolognesi and Hayashi, 2011). The evaluation of MN frequency plays a very important role for determination of genotoxic response of cells to different environmental contaminants (Hariri et al. 2018). This test is mostly used to determine in situ genotoxic potential of freshwater environments (Bolognesi and Hayashi, 2011). Contamination of these freshwater environments affect both aquatic and terrestrial organisms (Rocha et al., 2009).
Histidine biosynthesis is a metabolic pathway that occur in some living organisms such as bacteria, lower eukaryotes, plants and archaea. The fundamental regulatory processes of the histidine biosynthesis have been studied for many years mainly in bacteria such as Salmonella typhimurium and Escherichia coli (E. coli) (Kulis-Horn et al., 2014). Several tester strains of $S$. typhimurium such as TA98, TA100 etc have been developed for use in the mutagenic (Ames assay) that detect specific mutation types like base-pair or frameshift and are more sensitive for specific agents. TA100 is used to show basepair substitution mutations mainly at one of the GC pairs. The activation of this histidine in the tester strain measure the mutagenic activity of the test compound.

E. coli is capable of producing an enzyme called $\beta$-galactosidase ( $\beta$-gal). This enzyme breaks lactose into galactose and glucose. However, the gene for this enzyme is normally deactivated except in the presence of lactose. Induction of $\beta$-gal activity of an exposed organism is used indirectly to determine the genotoxic potential of a test compound (Nair et al., 2000). E. coli strain (PQ37) is used to show excisionrepair-deficient in wild-type, hence it is called Save Our Soul (SOS). The SOS Chromotest ${ }^{\mathrm{TM}}$ bacteria strain has undergone some modifications to increase sensitivity to genotoxins. Therefore, the two tester strains (S. typhimurium TA100 and E. coli $\mathrm{PQ} 37$ ) are developed respectively to test mutagenic and genotoxic materials of chemicals and/or pollutants. This led to our investigation on genotoxic/mutagenic potential on a major river (Asa river) that supply potable water for drinking for rapidly growing population of the people of Ilorin, Kwara state, Nigeria, and on its fauna (fishes) using Ames test - bacterial reverse mutation test and SOS Chromotest, recommended by regulatory agencies to detect genotoxic carcinogens (Kirkland et al.,2005). In addition, genotoxic potential of Asa river was investigated in different species of fish residing in it using peripheral erythrocyte micronucleus assay.

\subsection{Materials and Method}

\section{Study area}

Asa reservoir, in Aliara Temioda Village was constructed between May, 1975 and January,1977. It was constructed over the Asa river with the sole aim of meeting the ever-increasing demand for pipe-borne water for rapidly growing population of Ilorin, the state capital of Kwara State (Omotosho, 1998). It supplies more than a million people water per day. The reservoir is located at a point of about $5 \mathrm{~km}$ south of Ilorin across River Asa between latitude $8^{\circ} 25-8^{\circ} 27^{\prime} \mathrm{N}$ and longitude $4^{\circ} 32^{\prime}$ $4^{\circ} 34^{\prime \prime}$ E. The reservoir has maximum length of $20 \mathrm{~km}$, a breadth of $7 \mathrm{~km}$ and a depth of $14 \mathrm{~m}$, with a storage capacity of about 43 million cubic meters (Omotosho, 1998).

\section{Site Description}

Three (3) stations were selected which are Aliara (along the water body), Unity (at the spring of the river) and Tuyil (downstream of the river) as indicated in the map (Figure 1). Aliara (SI) is a small community located at Asa local government with coordinates of $8^{\circ} 34^{\prime} 0^{\prime \prime} \mathrm{N}$ and $4^{\circ} 34^{\prime} 0^{\prime \prime} \mathrm{E}$ in DMS. The water in this station is clean and useful for many activities. The villagers and nearby community depend on this water for drinking, irrigation, and source of income through 
commercial fishing. It is a source of water for Ilorin at large. Agriculture activities were being carried out near the river.

Unity station (SII) is also another site of Asa river with the coordinate of $8^{\circ} 34^{\prime} 0^{\prime \prime} \mathrm{N}$ and $4^{\circ} 34^{\prime} 0^{\prime \prime} \mathrm{E}$ in DMS. Different companies such as Dangote, Coca-cola Global soap and detergent company are located around the river. Little agricultural activities like Ugwu planting and cassava planting are also practiced near the river. The dumping of refuses, sewage disposal and effluent/chemicals disposal from the industry into the body of the river pollutes the water, making it appear unfit for drinking and for some other domestic activities. Different species of fish are available but not very abundant compared to Aliara. Tuyil station (SIII) is not very far from Unity station. It is located very close to Tuyil pharmaceutical company. The sewage discharge from this industry finds its way into the waterbody.

\section{Water Sample collection}

Water sample were taken from Asa river with a water sampler from the three stations between 8:00am and 9:00am at 30cm depth of the water surface using standard method (Boyd, 1995). The pH, conductivity and total dissolve solid were analyzed using Hanna Multiparameter H19812.The instrument was first calibrated and the readings were taken from the sample. The probe was rinsed twice before subsequent sample readings. Mineral analysis of Asa river was measured using the method described by Association of Official Analytical Chemist (AOAC, 2005) and AAS (Atomic Absorption Spectrophotometer) (model: Buck scientific ACCUS-IS 211) was used for $\mathrm{Cr}, \mathrm{Cd}, \mathrm{Pb}, \mathrm{Mn}, \mathrm{Cu}, \mathrm{As}, \mathrm{Fe}, \mathrm{Mg}$ and $\mathrm{Zn}$ heavy metals assessment in the sampled water from the three sites.

\section{Fish collections}

Two species $(\mathrm{n}=2)$ each of scale (Oreochromis niloticus) and scaleless (Synodontis batensoda, Synodontis eupterus, Clarias gariepinus and Clarias angullaris) fishes were caught with the assistance of a fisherman using gill nets from two different stations (SI and SII) of the Asa river for the micronucleus analysis. No fish was found in SIII. This experiment was done in triplicate

\section{Micronucleus Assay}

The fish blood was taken at the tail region vein and smeared immediately on a clean glass slides to air dried for 24 hours at room temperature, then fixing it in $70 \%$ methanol for 20 minutes. The fixed slides were allowed to air dried for another 24 hours and subsequently stained in 10\% May-Grunwald for 5 minutes. The slides were removed and rinsed briefly in distilled water and airdried overnight before staining in 5\% Giemsa stain for 5 minutes. The slides were removed and rinsed briefly in distilled water and dried overnight again before examining under microscope (Anifowoshe et al., 2018). The stained slides were examined for a total number of 1000 of erythrocytes from each fish with the use of a light microscope at 1000 times magnification for micronucleus and nuclear abnormalities as biomarkers of cyto-genotoxicity (Carrasco et al., 1990 and Ergene et al., 2007).

\section{MUTA-CHROMOPLATE Reverse Mutation (AMES TEST)}

The Muta-ChromoPlate ${ }^{\mathrm{TM}}$ (Ames test) is used for detection of mutagenic activity of a chemical or pollutants by observing the colour changes. It is a 96-well microplate version of the S. typhimurium. Thus, the tester strain S. typhimurium TA100 used in this study was obtained from Environmental Bio-Detection Products (EBPI) Inc., Canada to screen the water samples collected. This test was done without metabolic activation following a standard procedure of Legault et al. (1994) and Guan et al. (2017). Bacteria culture was prepared under aseptic condition. $5 \mathrm{ml}$ of growth media was added to lyophilized (dried) bacteria strains of $S$. typhimurium TA100 which was stored at $-20^{\circ} \mathrm{C}$. The mixture was thoroughly mixed and covered with a rubber stopper and incubated in an incubator overnight for 18 hours. For each site (SI, SII, and SIII), three dilutions (\%) (25, 50 and 100 (v/v: water sample/distilled water)) were made, filtered and sterilized using $0.22 \mu \mathrm{m}$ membrane filter as described in the EBPI manual guide. About $17.5 \mathrm{ml}$ of the filtered water samples each was measured and dispensed in clean $50 \mathrm{ml}$ tubes. Then we carried out reaction mixture as stated in EBPI (2016) guide. We mixed 22ml of Davis-Mingioli salt, $5 \mathrm{ml}$ D-glucose, $2.5 \mathrm{ml}$ Bromocresol purple, $2 \mathrm{ml}$ D-Biotin and $0.12 \mathrm{ml} \mathrm{L}$ histidine together into a sterile reaction mixture container. The reaction mixture of $2.5 \mathrm{ml}$ aseptically dispensed to sterile tube, each containing the tested samples and mixed thoroughly. $5 \mu$ l of cultured bacteria, S. typhimurium (TA100) was added to the treatment material in the sterile tube. The content was dispensed into a sterile reagent boat (multichannel pipette). $120 \mu$ l of the aliquot's mixture was then dispensed into a 96-well plate with a micropipette and sealed in a plastic bag to prevent vaporization. This was incubated for 5 days at $37^{\circ} \mathrm{C}$. All concentrations were carried out in triplicate.

Our data was expressed as Mutagenicity Ratio (MR);

$\mathrm{MR}=\quad$ No. of positive wells in treated plates number of positive wells in the negative control plates

\section{SOS-Chromo test}

E. coli PQ37 tester strain was obtained from EBPI, Canada Inc. (EBPI, 2016). Re-hydration of the dried bacteria was performed a day prior to the day the experiment was performed allowing for bacterial growth. The test was carried out without metabolic activation (Quillardet and Hofnung, 1985; Kevekordes et al. 1999; and Alabi et al. (2014; 2016). Briefly, the bacterium was grown overnight in a $37^{\circ} \mathrm{C}$ incubator to an Optical Density (OD) of 0.05 to 0.06 for approximately 16 hours. After bacterial growth, additional growth media (bottle A) was used for the dilution of bacterial suspension to the required OD of 0.05 at $600 \mathrm{~nm}$ before use in the assay to know the degree of bacterial growth obtained as described in the manual kit. For water sample (SI, SII, and SIII), three dilutions of $100 \%, 50 \%$ and $25 \% \mathrm{v} / \mathrm{v}$ with water sample/distilled water were made, filtered and sterilized using $0.22 \mu \mathrm{m}$ membrane filter. Then, overnight culture dilution of $600 \mu \mathrm{L}$ was added to a tube containing $20 \mu \mathrm{L}$ sample volume, and incubated with agitation at $37^{\circ} \mathrm{C}$ for 2 hours and subsequently centrifuged at 700 $\mathrm{g}$ for $20 \mathrm{~min}$. The supernatant was discarded to resuspended the bacterial pellets with $200 \mu \mathrm{L}$ of SOS Chromogen as described in the manual guide. 4-nitroquinoline-1-oxide (4-NQO) $(0.5 \mu \mathrm{g} / \mathrm{mL})$ was used as a positive control, and DMSO as a negative control. The 96-well plates were re-incubated with shaking at $150 \mathrm{rpm}$ (10 minutes for alkaline phosphatase (AP) as well as 60 minutes for $\beta$-gal). OD readings were recorded at $405 \mathrm{~nm}(\mathrm{AP})$ and 620 ( $\beta$-gal) respectively. 
The reduction factors (RF) of AP and induction factors (IF) of $\beta$ gal were determined as shown in the statistical analysis to calculate the genotoxic activity of the water samples at different concentrations. This test was also done in a triplicate.

\section{Statistical analysis}

The experimental values were presented as mean \pm standard error (SE). The Statistical Package for Social Science (SPSS) version 21.0 was applied to evaluate the micronucleus and the differences between the test groups. Two groups and multigroup comparisons of the mean were assessed out by multiple t-test and one-way analysis of variance (ANOVA) test, respectively and the level of statistical significance were estimated at $\mathrm{p}<0.05$ using the Duncan multiple range test (DMRT).

\pm Alkaline Phosphatase (AP) reduction factors (RF), ßgal induction factors (IF) and corrected induction factors (CIF-IF/RF) were calculated as described by Legault et al. (1996):

$\mathrm{RF}$ - XOD405t/XOD405c

IF - XOD620t/XOD620c

CIF - IF/RF

$\mathrm{X}=$ mean of four $\mathrm{OD}$ readings

$\mathrm{t}=$ test dilutions

$\mathrm{c}=$ control dilutions. Background activity of control was accounted for by the RF and IF values

$\mathrm{IF} / \mathrm{RF}$ units $=\beta$-gal activity

$\mathrm{IF} \geq 1.2$ was considered to represent significant genotoxic activity.

\subsection{Results}

The physicochemical parameters values of the water sample from the three different locations (SI, SII and SIII) of the river are shown in Table 1. Heavy metals like manganese (Mn), chromium (Cr) and Iron (Fe) were recorded at the three sites, lead $(\mathrm{Pb})$ cadmium $(\mathrm{Cd})$, copper $\mathrm{Cu}$ ) at SI and SII, as well as arsenic and zinc at SI only. At SI, Cr, Pb, Cd,
Fe and Arsenic (As) recorded were all above the permissible limit set by standard organizations (USEPA, WHO and NESREA) in drinking. At SII and SIII, $\mathrm{Cr}$ and $\mathrm{Cd}$; and $\mathrm{Cr}, \mathrm{Mn}, \mathrm{Mg}$ and Fe were also above the standard limit for good water quality respectively.

The photomicrograph of the MN and NA are shown in Figure 2. Micronucleated cells and other nuclear abnormalities such as binucleated, blebbed, kidney-shaped, vacuolated, nuclear fragment, enucleated and karyolysis were observed and presented in this figure. Figure 3 showed the mean abnormalities induced in various fish species by the water sample from SI and SII. The order of abnormalities in the various fish species from the two stations are: Synodontis batensoda $>$ Synodontis eupterus $>$ Oreochromis niloticus (SI) and Oreochromis niloticus $>$ Clarias angullaris $>$ Clarias gariepinus (SII). The mean frequency of the anomalies was higher in all the fishes at SI compare to SII. No fish was found in SIII.

The summary of erythrocytes counted for MN and NA from these fishes indicated a significant $(\mathrm{p}<0.05)$ in the two scaleless fishes $(S$. batensoda and S. eupterus) at SI and the scale fish (O. niloticus) at SII (Table 2). When pulled together, the result showed that micronuclei frequencies were more in scaleless fishes particularly those of SI than the scale fishes (Figure 3). Table 3 shows the genotoxicity of the water samples at various sites as evaluated by the Ames $S$. typhimurium (TA100) at different concentrations. The positive were determined by turbid, slightly yellow and yellow well colouration while the purple wells indicate negative. A statistically significant $(\mathrm{p}<0.05)$ increase in the level of MI at all concentrations was observed. However, Table 4 shows genotoxic effect as tested by the SOS chromotest as well as the level of genotoxic induction factors (IF) in the water samples from the three sites. IF $\geq 1.2$ was considered genotoxic using a positive $(+)$ sign or negative (-) sign below 1.2. Thus, the result from this table indicate the level of induction in the following ascending order (SIII $>$ SI $>$ SII).

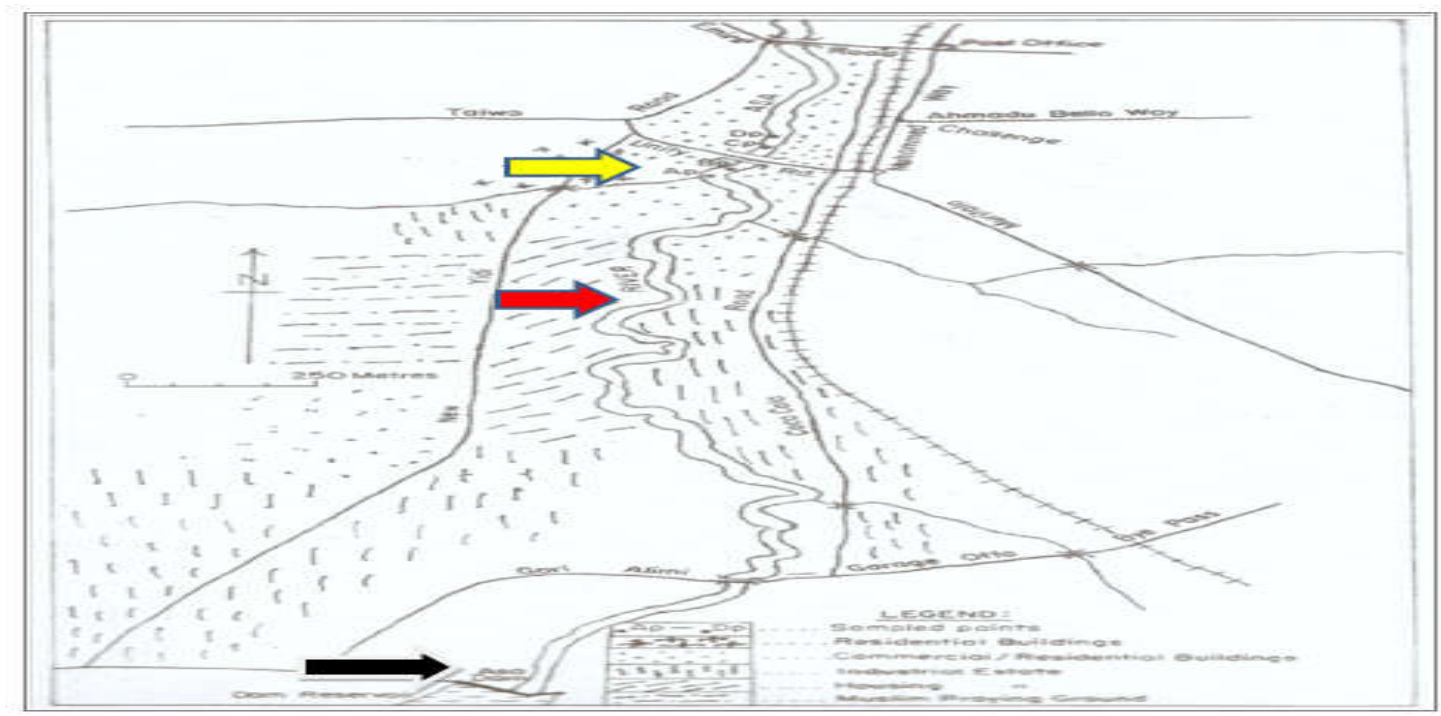

Figure 1: Map of Asa River with arrows indicating sampling location. SI rivers (black arrow), SII (yellow arrow), SIII (red arrow)

Adapted from Kolawole et al. (2011) 
Table 1: Physico-chemical and heavy metals parameters of Asa river along the 3 sites

\begin{tabular}{|c|c|c|c|c|c|c|}
\hline Parameters & SI & SII & SIII & USEPA & WHO & NESREA \\
\hline pH & 5.7 & 5.7 & 5.0 & $6.5-8.5$ & $6.5-8.5$ & $6.1-9.0$ \\
\hline TDS (Mg/dl) & 430 & 250 & 380 & 500 & - & 500 \\
\hline Cond. $(\mu S / \mathrm{cm})$ & 860 & 120 & 750 & - & - & - \\
\hline $\operatorname{Temp}\left({ }^{\circ} \mathrm{C}\right)$ & 31 & 31 & 29 & - & - & - \\
\hline DO (Mg/dl) & 5.800 & 4.200 & 3.600 & - & $>2$ & - \\
\hline BOD (Mg/dl) & 4.400 & 0.700 & 1.500 & 250 & $>6$ & - \\
\hline COD (Mg/dl) & 5568 & 2176 & 96 & 410 & - & 90 \\
\hline $\operatorname{Cr}(p p m)$ & 4.256 & 0.102 & 0.500 & 0.100 & - & 0.050 \\
\hline $\mathrm{Pb}(\mathbf{p p m})$ & 2.714 & 0.224 & 0.000 & 0.015 & $<1$ & 0.500 \\
\hline Cd (ppm) & 2.380 & 0.41 & 0.000 & 0.050 & - & 0.200 \\
\hline Mn (ppm) & 0.028 & 0.028 & 0.600 & 0.050 & 5.000 & 0.300 \\
\hline As (ppm) & 0.265 & 0.000 & 0.000 & - & - & - \\
\hline $\mathrm{Cu}(\mathrm{ppm})$ & 1.275 & 0.250 & 0.000 & 1.300 & $<1$ & 0.500 \\
\hline Zn (ppm) & 3.056 & 0.000 & 0.000 & 5.000 & $<1$ & 5.000 \\
\hline Mg (ppm) & 4.640 & 0.000 & 0.366 & - & - & - \\
\hline $\mathrm{Fe}(\mathrm{ppm})$ & 2.778 & 0.384 & 3.533 & 0.300 & 20 & 0.300 \\
\hline
\end{tabular}

- TDS: total dissolved solid; Cond.: Conductivity; DO: dissolve oxygen; BOD: biological oxygen demand; COD: chemical oxygen demand;

- Cr: chromium; Pb: Lead; Cd: cadmium; Mn: Manganese; As: Arsenic; Cu: copper; Zn: Zinc; Mg: Magnesium; Fe: Iron

- USEPA US Environmental Protection Agency.

- WHO: World Health Organization

- NESREA: National Environmental Standards and Regulations Enforcement $(-)$ : No value

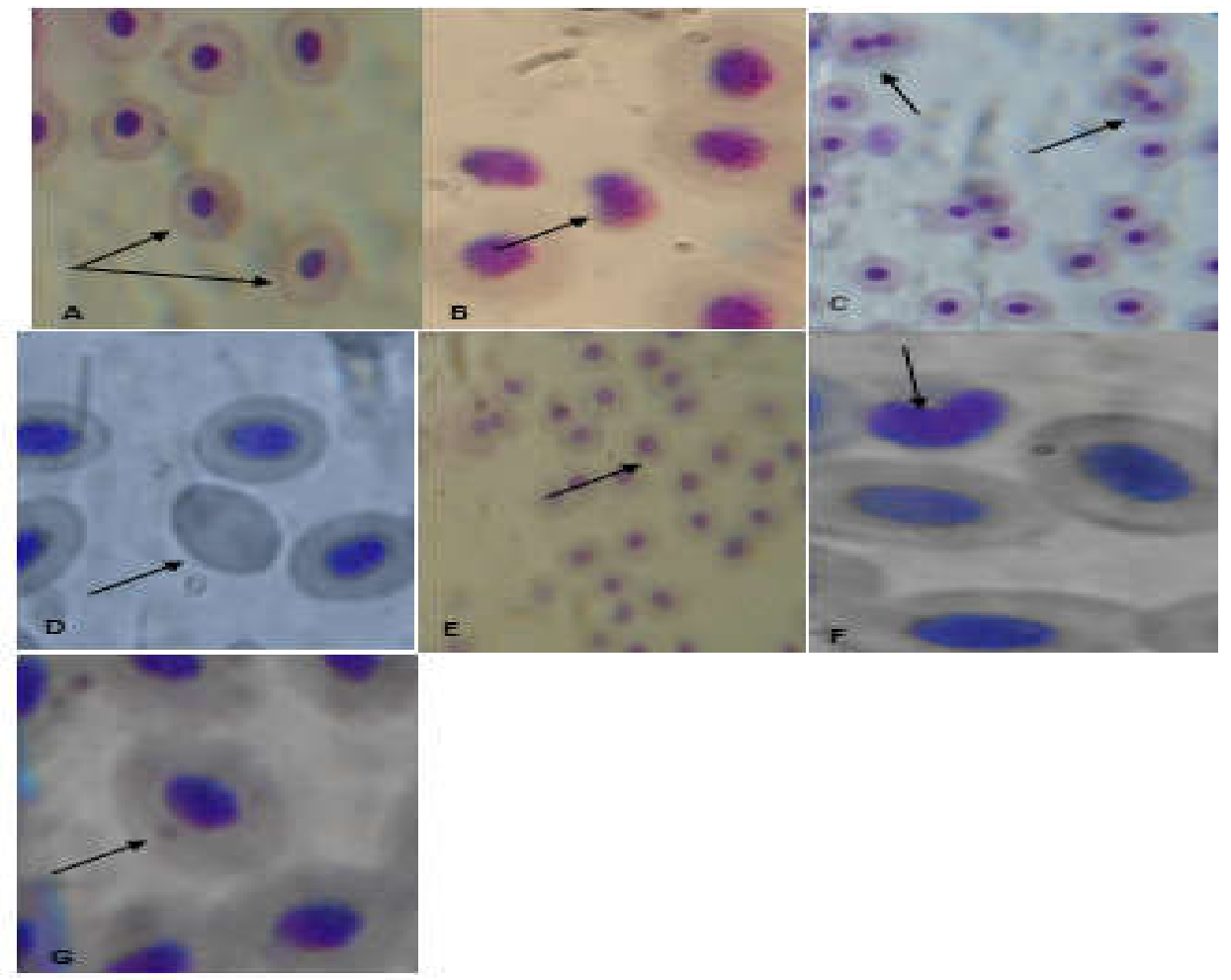

Figure 2: Normal erythrocyte, micronucleated erythrocyte, and nuclear abnormalities by the water sample in the selected fish species from the Asa River (Mag. $\times 1000$ )

A=Normal erythrocyte B=Blebbed shape $\mathrm{C}=$ Binucleated cells $\mathrm{D}=$ Enucleated cell $\mathrm{E}=$ Vacuolated nuclear F= Kidney shaped G= Micronucleated cell 


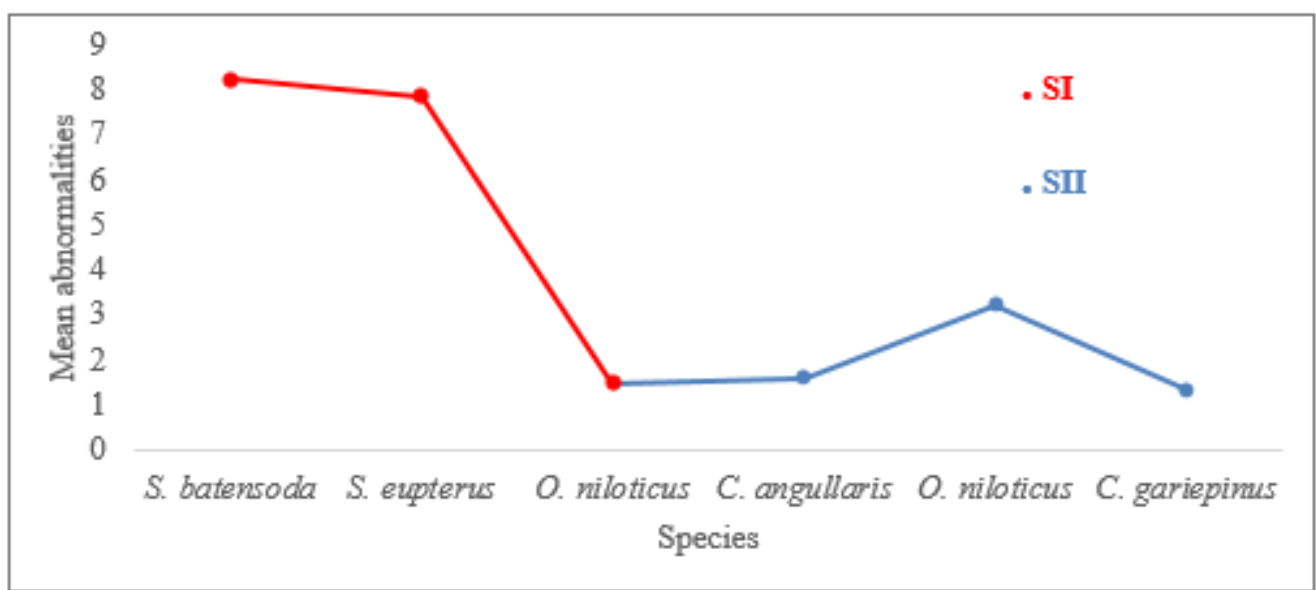

Figure 3: Mean abnormalities induced in various fish species by the water sample from SI and SII

Table 2: Summary of micronuclei induction and nuclear abnormalities observed in different species of fish at SI and SII sites

\begin{tabular}{llllllllllll}
\hline Sites & Species & MN & BN & B & KS & NF & V & K & E & Total & Mean \pm SE \\
\hline SI & S. batensoda & 13 & 36 & 0 & 13 & 3 & 1 & 0 & 0 & 66 & $8.250 \pm 6.5001^{*}$ \\
& S. eupterus & 14 & 37 & 0 & 0 & 11 & 0 & 0 & 1 & 63 & $7.875 \pm 6.5001^{*}$ \\
& O. niloticus & 1 & 5 & 1 & 0 & 2 & 1 & 1 & 1 & 12 & $1.50 \pm 0.0000$ \\
SII & C. angullaris & 2 & 2 & 4 & 1 & 1 & 1 & 1 & 1 & 13 & $1.625 \pm 0.5000$ \\
& O. niloticus & 4 & 1 & 3 & 0 & 0 & 1 & 1 & 16 & 26 & $3.250 \pm 6.0000^{*}$ \\
& C. gariepinus & 3 & 2 & 1 & 0 & 0 & 1 & 2 & 2 & 11 & $1.375 \pm 0.5000$
\end{tabular}

MN: Micronucleus; BN: Binucleated, BL: Blebbed; KS: Kidney shape; VN: Vacuolated; K: Karyolysis, E: Enucleated.

Table 3: SI, SII and SIII genotoxicity as tested by the Ames Salmonella typhimurium (TA100) at different concentrations.

\begin{tabular}{|c|c|c|c|}
\hline Sites & Conc. (\%) & Mean \pm SE & MR \\
\hline NC & $(\mathrm{DW})$ & $80.67 \pm 0.58$ & - \\
\hline \multirow[t]{3}{*}{ SI } & 25 & $16.67 \pm 0.58^{*}$ & $5.3^{*}$ \\
\hline & 50 & $6.93 \pm 0.12^{*}$ & $5.9^{*}$ \\
\hline & 100 & $6.83 \pm 0.28^{*}$ & $5.9^{*}$ \\
\hline \multirow[t]{3}{*}{ SII } & 25 & $58.33 \pm 0.58^{*}$ & 2.6 \\
\hline & 50 & $66.68 \pm 0.57^{*}$ & 1.9 \\
\hline & 100 & $54.93 \pm 0.12^{*}$ & 2.7 \\
\hline \multirow[t]{3}{*}{ SIII } & 25 & $11.90 \pm 0.17^{*}$ & $5.6^{*}$ \\
\hline & 50 & $5.97 \pm 0.06^{*}$ & $6.1^{*}$ \\
\hline & 100 & $78.33 \pm 0.58^{*}$ & 1.1 \\
\hline PC & $\mathrm{NaN}_{3}$ & $11.90 \pm 0.17^{*}$ & 5.6 \\
\hline
\end{tabular}

*Statistically significant at $\mathrm{p} \leq 0.05$

MR *Statistically significant at $\mathrm{p}<0.01$; DW: Distilled water; $\mathrm{NaN}_{3}$ : Sodium azide

$\mathrm{MR}=$ mutagenicity ratio (number of positive wells in treated plates/number of positive wells in the negative control plates)

NC: Negative control; SI: Aliara site; SII: Unity site; SIII: Tuyil site; PC: Positive control 
Table 4: SI, SII and SIII genotoxicity as tested by the SOS chromotest at different concentrations.

\begin{tabular}{|c|c|c|c|c|}
\hline Sample & Concentrations & IF & Genotoxicity & Mean \pm SE \\
\hline NC (DMSO) & - & - & - & $0.087 \pm 00$ \\
\hline \multirow[t]{3}{*}{ SI } & $25 \%$ & 0.079 & - & $0.079 \pm 00$ \\
\hline & $50 \%$ & 0.870 & - & $0.870 \pm 19$ \\
\hline & $100 \%$ & 1.230 & + & $1.230 \pm 24^{*}$ \\
\hline \multirow[t]{3}{*}{ SII } & $25 \%$ & 1.882 & + & $1.882 \pm 19 *$ \\
\hline & $50 \%$ & 1.049 & - & $1.049 \pm 01^{*}$ \\
\hline & $100 \%$ & 1.307 & + & $1.307 \pm 14^{*}$ \\
\hline \multirow[t]{3}{*}{ SIII } & $25 \%$ & 0.929 & - & $0.929 \pm 19$ \\
\hline & $50 \%$ & 0.907 & - & $0.907 \pm 16$ \\
\hline & $100 \%$ & 1.030 & - & $1.030 \pm 54^{*}$ \\
\hline Positive & $20 \mu \mathrm{l}$ & 1.601 & + & $1.447 \pm 49$ \\
\hline (4-NQO) & & & & \\
\hline
\end{tabular}

$(+)=$ Genotoxic; $(-)$ = Not Genotoxic

DMSO: Dimethyl sulfoxide

4-NQO: 4-nitroquinoline-1-oxide

$\mathrm{IF}=$ Induction Factor

$\mathrm{IF} \geq 1.2$ is considered genotoxic

\subsection{Discussion}

Water is an indispensable natural product that is very important to both aquatic and terrestrial animals but pollutions of this natural resources is of great concern. This study investigated the genotoxic, mutagenic potential of water sample from Asa river as well as on different fish species inhabiting the river using three bioassays micronucleus (MN) assay, SOS Chromotest and bacterial reverse mutation (Ames) test.

Pollution of water bodies with indiscriminate discharge of unwanted wastes is a global issue due to the danger that the polluted waters contain that may be teratogenic, mutagenic and carcinogenic and thus promotes the occurrence of human diseases such as cancer, atherosclerosis, cardiovascular disease and premature aging. The results of the heavy metals and the physico-chemical parameters analyzed from the three sites in this study were above the limit permissible by standard organization. This imply that the river is polluted and thus not suitable for drinking.

Previous works have demonstrated that in aquatic ecosystems, the best genetic model for pollution assessment is fish (Mitchell and Kennedy, 1992; Park et al.,1993; Anifowoshe et al., 2018), however, most of the aquatic ecosystems are still used for waste disposal for all waste produced by man. The consequence of this will not only affect the aquatic animals but also the terrestrial animals. According to Ali et al. (2008), the aquatic ecosystem contributes enormously to our habitats and resources, thus its harmlessness is directly proportional to the well-being of our health. In this study, MN assay which is considered as a robust tool for the detection of DNA damage and pollution bioindicators due to it sensitivity was used. The fishes collected from all the stations except in SIII showed the formation of MN and nuclear abnormalities (NA) most especially among the scaleless fish (S. batensoda and S. eupterus of SI, C. angullaris and $C$. gariepinus of SII). This might be as a result of indifference in accumulation of food by the fishes because according to Ademoroti, (1996), aquatic animals with high intake of food tend to accumulate more pollutants than others. This study is in line with the reports of the reports of previous research on pollution assessment using MN assay (Palhares and Grisolia, 2002; Bustamante et al., 2003; Anifowoshe et al., 2018).The absence of fish at SIII site may be due to low level of water in the site when compare to SI and SII or as a result of fresh chemical effluents that are released daily from the Tuyil pharmaceutical industry into the site which may not be suitable for reproduction, growth and development of fish in it depending on the species that may be present. Also, it may also be as a result of low-level dissolved oxygen (DO) recorded at SIII when compare to SI and SII. Therefore, this result demonstrates a very important role for determination of genotoxic response of cells to different influx of environmental pollutants (Hariri et al., 2018)

Ames assay is sensitive and powerful tool to measure mutagenicity in water samples than the classical Ames test (Monarca et al., 1985). Our results showed base-pair substitution oxidative reverse mutation at different of concentrations of $25 \%, 50 \%$, and $100 \%$ sample water obtained from the three (3) sites. The implication of this is that if mutation occur in the exon, then it could have an effect on the histidine biosynthesis (protein primary structure). Changes in the biosynthesis of histidine may be caused by gene (point) mutations, frameshift mutations, chromosome breaks, as well as chromosomes loss or gain. (Mortelmans and Zeiger, 2000). Our result is also similar to the report of Alabi et al. (2013). Tobacco wastewater was also shown to be toxic to coliforms (Sponza, 2002). Therefore, this test has a large anticipating value for cancer formation (Aydogan and Kutlu 2007; Benkli et al., 2009).

SOS chromotest enables the detection of DNA damage on E. coli by different agents. Our study revealed that SI SII and SIII contained agents with ability to induce SOS response in the strain (E. coli (PQ37)). Generally, a significant induction of mutagenic response was observed along the three (3) sites which is concentration dependent. SOS- 
Chromo test strain showed a significant response in terms of mutagenicity induction against the water samples than Ames test, however, both tests (SOS-Chromo and Ames tests) have similar effect and concentration dependence. Although the SOS chromotest results were not in agreement with those of the Ames Salmonella fluctuation test at SIII site except at $100 \%$ concentration, notwithstanding, the $E$. coli PQ37 system showed more sensitivity in the test samples than the Salmonella assay in determination of genotoxins potential.

Heavy metals levels in all the three sites may contribute significantly in the observed mutagenicity and genotoxicity since nickel, cadmium and arsenic are classified as carcinogens. Although the mechanism of action of the carcinogenesis is undefined, heavy metal exposure has been described to inducing double strand breaks (DSBs) as well as inhibiting critical proteins from different DNA repair pathways leading to genetic damages (Morales et al., 2016). Over accumulation of these heavy metals as observed in this study could have increased the risk of free radicals to cause DNA damage in the tested organisms. Therefore, these free radicals might be responsible for DNA damage observed in the fish species and base pair substitution mutations and excisionrepair-deficient in the two tester strains. Our work is in accordance to Kolawole et al. (2011) wherein a remarkable distinction of higher bacterial density was reported when compared the intestinal and liver tissues of Clarias gariepinus from Asa river. Our work is also in line with established records from previous studies, therein they showed the water sample from this river is not suitable for drinking (Eletta et al., 2005; Adekunle and Eniola, 2008, Adekunle, 2009, Edwin and Muritala, 2013; Olawale, 2016).

\section{Conclusion}

Asa river, an important river in Ilorin, Kwara State, Nigeria supplies the whole community with potable water for drinking, however, agricultural, industrialization and anthropogenic activities are polluting the water and also killing or decreasing the fish abundance. The results of this study at the three (3) different sites confirm the potential genotoxic and mutagenic effects of the water body. The E. coli PQ37 system of the SOS Chromotest showed more sensitivity than the Ames test for detecting genotoxic substances. The upstream to downstream of the river showed a pollution burden that can be of a genotoxic risk, thus drinking the water or consuming the fishes should be done with caution. Therefore, future genotoxic work is needed on this major river in the state.

\section{Acknowledgement}

We acknowledge the Technical Staff of the Central Research Lab, University of Ilorin, Ilorin, Nigeria for the facility provided and also the people of Aliara Temioda Village living around the Asa reservoir for their hospitality during sampling collection.

\section{Declaration of Conflict of Interests}

The authors declare no conflict of interests.

\section{Funding}

This study received no fund from any agency.

\author{
Authors' Contributions \\ Conception: ATA, OSO \\ Design: ATA, OSO, AIS \\ Execution: AOM, EOS, AAR, AAM, OTI, AAK 1, YOH, AAK 2 , TOS, OOR
}

Interpretation: ATA, AIS, OSO

Writing the manuscript: ATA, AOM, EOS

\section{References}

Adekunle, A.S., 2009, Effects of industrial effluent on quality of well water within Asa dam Industrial estate, Ilorin Nigeria. Nature and Science, 7(1): 39-42

Adekunle, A.S., Eniola, I.T.K., 2008, Industrial effluents on quality of segment of Asa River within an industrial estate in Ilorin, Nigeria. New York Science Journal. 1:17-21.

Ademoroti, C.M.O., 1996, Standard methods for water and effluents analysis. Ibadan: Foludex Press Ltd. 3: 29-118.

Alabi, O.A., Bakare, A.A., 2011, Genotoxicity and mutagenicity of electronic waste leachates using animal bioassays. Toxicological \& Environmental Chemistry, 93(5):1073-1088.

Alabi, A.O., Esan, E.B., Duru, C., Oyedele P., Salihu G.R, 2016, Mutagenicity of automobile workshop soil leachate and tobacco industry wastewater using the Ames Salmonella fluctuation and the SOS chromotests. Toxicological and Industrial Health, 32(6): 10861096.

Alabi, A.O., Esan, E.B., Odunukan, O.C., Shokunbi, O.S., 2014, Assessment of the mutagenic and genotoxic potential of indomie noodle seasoning using bacterial (Salmonella) reverse mutation and SOS Chromo tests. Journal of Innovative Biology, 1(4); 210-214.

Alabi, O.A., Omosebi, O., Chizea, I., 2013, Determination of the mutagenic and genotoxic potential of simulated leachate from an automobile workshop soil on eukaryotic system. Toxicological and Industrial Health, 1(1):9. Epub ahead of print 20 March 2013. DOI: 10.1177/0748233713483206. DOI: 10.1177/0748233713483206.

Ali, F.K., El-Shewawi, A.M., Seehy, M.A., 2008, Micronucleus test in fish genome: A sensitive monitor for aquatic pollution. African Journal of Biotechnolgy, 7 (5): 606-612.

Anifowoshe, A.T., Oladipo, S.O., Owolodun, O.A., Akinseye, M.K., Olafimihan, T.F., Sidiq, A.G, Muhammed, A.A., Asa, T.A., Mustapha, M.K., 2018. Ecogenotoxicogical assessments of some selected fish species from Apodu reservoir, Malete, North central, Nigeria, Manilla Journal of. Science, 11:1-14.

AOAC 2005, Official method of Analysis. 18th Edition, Association of Officiating Analytical Chemists, Washington DC, Method 935.14 and 992.24.

Aydogan, G., Kutlu, M., 2007, Mutagenic activities of ten imidazole derivatives in Salmonella typhimurium. Biologia, 62(1): 6-12.

Ayoola, S.O., 2008, Histopathological effects of glyphosate on juvenile African catfish (Clarias gariepinus). American-Eurasian Journal of Agricultural and Environmental Sciences, 4(3): 362-367.

Benkli, K.Y., Tunali, Z., Canturk, O., Artagan, O., Alanyali, F., 2009, Cytotoxic and genotoxic effects of $\left[\mathrm{Ru}(\mathrm{phi})_{3}\right]^{2+}$ evaluated by Ames/Salmonella and MTT methods. European Journal of Medicinal Chemistry, 44: 2601-2605. 
Bolognesi, C., Hayashi, M., 2011, Micronucleus assay in aquatic animals. Mutagenesis. 26: 205-213.

Boyd, C.E., 1995, Water Quality in Warm Water Fish ponds. Agricultural Station, Auburn, Alabama.

Bustamante, P., Bocher, P., Cherel, Y., Miramand, P., Caurant, F., 2003, Distribution of trace elements in the tissues of benthic and pelagic fish from the Kerguelen Islands. Science Total Environment, 313: 25-39.

Carrasco, K.R., Tilbury, K.L., Myers, M.S., 1990, Assessment of the piscine micronucleus test as in situ biological indicator of chemical contaminant effects. Canadian Journal of Fisheries and Aquatic Sciences, 47, 2123-2136.

Edwin, A.I., Muritala, A.I., 2013, Determination of water quality index of river Asa, Ilorin, Nigeria. Advances in Applied Science Research, 4(6):277-284

Eletta O.A., Adekola F.A., Aderanti M.A., 2005, Assessment of Asa River: Impact of waste discharge from soft drink plant into Asa River, Ilorin. Nigerian. Journal of Applied Sciences and Environmental Management, 9:187-190.

Ergene, S., Cavas, T., Celik, A., Koleli, N., Aymak, C., 2007, Evaluation of river water genotoxicity using piscine micronucleus test. Environmental and Molecular Mutagenesis, 48, 421-429.

Guan Y, Wang X, Wong M, Sun G, An T, Guo J., Zhang G., 2017, Evaluation of Genotoxic and Mutagenic Activity of Organic Extracts from Drinking Water Sources. PLoS ONE, 12(1): e0170454. doi:10.1371/journal.pone.0170454

Hariri, M., Mirvaghefi, A., Farahmand, H., Taghavi, L., Shahabinia, A., 2018, In situ assessment of Karaj River genotoxic impact with the alkaline comet assay and micronucleus test, on feral brown trout (Salmo trutta fario) Environmental Toxicology and Pharmacology, 58: 59-69.

Kevekordes, S., Mersch-Sundermann, V., Burghaus, C.M., Spielberger, J., Schmeiser, H.H., Arlt, V. M., Dunkelberg, H., 1999, SOS induction of selected naturally occurring substances in Escherichia coli (SOS chromotest). Mutation Research, 445:81-91

Kim, I.Y., Hyun, C.K., 2006, Comparative evaluation of the alkaline comet assay with the micronucleus test for genotoxicity monitoring using aquatic organisms. Ecotoxicological and Environmental Safety, 64: 288-297.

Kirkland, D., Aardema, M., Henderson, L., Miller, L., 2005, Evaluation of the ability of a battery of three in vitro genotoxicity tests to discriminate rodent carcinogens and non-carcinogens I. Sensitivity, specificity and relative predictivity. Mutation Research, 4:584 (1-2): 1256

Kligerman, A. D., 1982, Fishes as biological detectors of the effects of genotoxic agents. In J. Heddle (Ed.), Mutagenicity: New horizons in genetic toxicology (pp.435-456). New York: Academic Press.

Koshy, M., Nayar, T.V., 1999, Water quality aspects of River Pamba. Pollution Research,18(4):501-510.

Kolawole, O.A., Ajayi, K.T., Olayemi, A.B., Okoh, A.I., 2011, Assessment of water quality in Asa River (Nigeria) and its indigenous Clarias gariepinus Fish. International Journal of Environmental Research and Public Health, 8(11):4332-4352

Kulis-Horn, R.K., Persicke, M., Kalinowski, J., 2014, Histidine biosynthesis, its regulation and biotechnological application in Corynebacterium glutamicum. Microbial Biotechnology, 7(1):5-25

Kushwaha, B., Pandey, S., Sharma, S., Srivastava, R., Kumar, R., Nagpure, N.S., Dabas, A.,Srivastava, S.K., 2012, In situ assessment of genotoxic and mutagenic potential of polluted river water in Channa punctatus and Mystus vittatus. International Aquatic Research, 4, 16

Lee, R.F., Steinert, S., 2003, Use of the single cell gel electrophoresis/comet assay for detecting DNA damage in aquatic (marine and freshwater) animals. Mutation Research-Review in Mutation Research, 544: 43-64.

Legault R, Blaise C, Rokosh D, Chong-Kit R. 1994, Comparative assessment of the SOS chromotest kit and the Mutatox test with the Salmonella plate incorporation (Ames test) and fluctuation tests for screening genotoxic agents. Environmental Toxicology and Water Quality, 9(1): 45-57.

Legault, R., Blake, C., Trottier, S., 1996, Detecting genotoxic activity in industrial effluents using the SOS chromotest microplate assay. Environmental Toxicology and Water Quality, 11:151-165.

Llobet, J.M., Domingo, M., Gomez, J.M., Tomás J.M., Corbella, J., 2003, Acute toxicity studies of aluminum compounds: Antidotal efficacy of several chelating agents. Annual Review of Pharmacology and Toxicology, 60:80-83.

Mitchell, S., Kennedy, S., 1992, Tissue Concentrations of Organochlorine Compounds in Common Seals from the Coast of Northern Ireland. Science Total Environment, 115: 235-240.

Monarca, S., Pasquini, R., Arcaleni, P., 1985, Detection of mutagens in unconcentrated and concentrated drinking water supplies before and after treatment using microscale fluctuation test. Chemosphere 14:1069-1080.

Morales, M. E., Derbes, R.S., Ade, C. M., Ortego, J.C., Stark, J., Deininger, P.L., Roy-Engel, A.M., 2016, Heavy Metal Exposure Influences Double Strand Break DNA Repair Outcomes, PLoS One, v.11(3) :e0151367. doi: 10.1371/journal.pone.0151367

Mortelmans, K., Zeiger, E., 2000, The Ames Salmonella/microsome mutagenicity assay. Mutation Research/Fundamental and Molecular Mechanisms of Mutagenesis. 455(1-2):29-60.

Nair, P.P., Davis, K.E., Shami, S., Lagerholm, S., 2000, The induction of SOS function in Escherichia coli K-12rPQ37 by 4-nitroquinoline oxide 4-NQO and fecapentaenes-12 and -14 /is bile salt sensitive: implications for colon carcinogenesis. Mutation Research, 447: 179185.

Nwani, C.D., Nagpure, N.S., Kumar, R., Kushwaha, B., Kumar, P., Lakra, W.S. 2011,Mutagenic and genotoxic to freshwater fish Channa punctatus assessment of atrazinebased herbicide (Bloch) micronucleus test and single cell gel electrophoresis. Environmental Toxicology and Pharmacology, 31:314-322. 
Olawale S.A. 2016, Physico Chemical analysis of water from Asa River, Ilorin, Nigeria. Imperial Journal of Interdisciplinary Research, 2(3): 122-129

Omotosho, J.S. 1998, Ichthyofauna diversity of Asa reservoir, Ilorin, Nigeria. Bioscience Biotechnology Research Communications, 10(1):75-81.

Palhares, D., Grisolia, C.K., 2002, Comparison between the micronucleus frequencies of kidney and ill erythrocytes in tilapia fish, following mitomycin C treatment. Genetics and Molecular Biology, 25(3):281-284.

Park, E, Lee, J., Etoh, H., 1993, Fish Cell line (ULF-23HU) Derived from the Fin of the Central Mudminnow (Umbra limi): Suitable Characteristics for Clastogenicity Assay. In Vitro Cellular \& Developmental Biology, 25: 987-994.

Quillardet P., Hofnung, M., 1985, The SOS Chromotest, a colorimetric bacterial assay for genotoxins: procedures. Mutation Research, 147:65-78.
Rocha, P.S., Luvizotto, G.L., Kosmehl, T.B., Böttcher, M., Storch, V., Braunbeck T., Hollert, H., 2009, Sediment genotoxicity in the Tietê River (São Paulo, Brazil): in vitro comet assay versus in situ micronucleus assay studies. Ecotoxicological and Environmental Safety, 72(7):1842-1848

Sponza, D., 2002, Incorporation of toxicity tests into the Turkish industrial discharges monitoring systems. Archives of Environmental Contamination and Toxicology, 43(2): 186-197. 